\title{
New Spectrophotometric and Conductometric Methods for Macrolide Antibiotics Determination in Pure and Pharmaceutical Dosage Forms Using Rose Bengal
}

\author{
Rania A. Sayed, Wafaa S. Hassan, Magda Y. El-Mammli, and Abadalla Shalaby \\ Department of Analytical Chemistry, Faculty of Pharmacy, Zagazig University, Zagazig 44519, Egypt \\ Correspondence should be addressed to Rania A. Sayed; raniaadelsayed@yahoo.com
}

Received 20 June 2012; Revised 30 November 2012; Accepted 30 November 2012

Academic Editor: María Carmen Yebra-Biurrun

Copyright (C) 2013 Rania A. Sayed et al. This is an open access article distributed under the Creative Commons Attribution License, which permits unrestricted use, distribution, and reproduction in any medium, provided the original work is properly cited.

\begin{abstract}
Two Simple, accurate, precise, and rapid spectrophotometric and conductometric methods were developed for the estimation of erythromycin thiocyanate (I), clarithromycin (II), and azithromycin dihydrate (III) in both pure and pharmaceutical dosage forms. The spectrophotometric procedure depends on the reaction of rose bengal and copper with the cited drugs to form stable ternary complexes which are extractable with methylene chloride, and the absorbances were measured at 558, 557, and $560 \mathrm{~nm}$ for (I), (II), and (III), respectively. The conductometric method depends on the formation of an ion-pair complex between the studied drug and rose bengal. For the spectrophotometric method, Beer's law was obeyed. The correlation coefficient $\left(r^{2}\right)$ for the studied drugs was found to be 0.9999 . The molar absorptivity $(\varepsilon)$, Sandell's sensitivity, limit of detection (LOD), and limit of quantification (LOQ) were also calculated. The proposed methods were successfully applied for the determination of certain pharmaceutical dosage forms containing the studied drugs
\end{abstract}

\section{Introduction}

The macrolides are a large group of antibiotics mainly derived from Streptomyces. They have a common macrocyclic lactone ring to which one or more sugars are attached and are all weak bases that are only slightly soluble in water [1]. They are bacteriostatic agents. They inhibit protein synthesis by binding reversibly to $50 \mathrm{~S}$ ribosomal subunit of sensitive microorganisms [2]. Macrolides and related drugs have a postantibiotic effect, that is, antibacterial activity persists after concentrations have dropped below the minimum inhibitory concentration [1].

Erythromycin is produced by the actinomycete species, Streptomyces erythreus. Erythromycin is a polyhydroxylactone that contains two sugars. The aglycone portion of the molecule, erythranolide, is a 14-membered lactone ring. An amino sugar, desosamine, is attached through a $\beta$ glycosidic linkage to the $\mathrm{C}-5$ position of the lactone ring. The tertiary amine of desosamine confers a basic character to erythromycin (pKa 8.8). Through this group, a number of acid salts of the antibiotic have been prepared. A second sugar, cladinose, which is unique to erythromycin, is attached via a $\beta$-glycosidic linkage to the $\mathrm{C}$-3 position of the lactone ring [3]. It is commonly used to treat infections caused by gram-positive organisms, Mycoplasma species, and certain susceptible gram-negative and anaerobic bacteria within respiratory tract, skin, soft tissues, and genital tract [4].

More recently developed macrolides, including azithromycin and clarithromycin, seem to have essentially similar properties to erythromycin, which is a natural macrolide, though they may differ in their pharmacokinetics. Clarithromycin and, to a lesser extent, azithromycin are more active than erythromycin against opportunistic mycobacteria such as Mycobacterium avium complex. Clarithromycin is also used in the treatment of leprosy and in regimens for the eradication of Helicobacter pylori in peptic ulcer disease. Both azithromycin and clarithromycin have activity against protozoa including Toxoplasma gondii. Gastrointestinal disturbances are the most frequent adverse effect but are usually mild and less frequent with clarithromycin and azithromycin than with erythromycin [1]. 
The literature search revealed different techniques for the analysis of the studied macrolides. The British Pharmacopoeia (BP) stated the liquid chromatography method for the assay of erythromycin, clarithromycin and azithromycin [5]. Also, the cited drugs have been analyzed spectrophotometrically in pharmaceutical dosage forms and biological fluids [6-10] and spectrofluorimetrically [11, 12]. Other methods have been published for the cited drugs either in pharmaceutical preparations and biological fluids such as capillary electrophoresis [13, 14], HPLC [15-17], and voltametry [18]. A microbiological method was reported for the assay of erythromycin thiocyanate [19] and azithromycin [20].

The majority of the reported methods are HPLC methods which require complex and expensive equipment, intensive sample preparation, and personnel skilled in chromatographic techniques. Also, Due to weak UV absorbance of macrolide antibiotics, it is difficult to develop a simple method for analysis of the drugs in pharmaceutical applications and biological fluids using conventional UV detection, so there is a need for simple spectrophotometric method for the analysis of the cited drugs in pharmaceutical formulations. So, the aim of this work is to develop simple, sensitive, accurate, and cheap spectrophotometric (through ternary complex formation with rose bengal and copper) and conductometric mehods (through ion pair formation with rose bengal) for the determination of three macrolide drugs in pure form and in the pharmaceutical preparations.

Rose bengal has been used as ion-pair-forming agent for determination of chlorphenoxamine hydrcholoride, anhydrous caffeine [21], and oxybuprocaine hydrochloride [22]. It was also used for conductometric determination of clindamycin hydrochloride through ion-pair formation [23], and it was also used for determination of isoniazide, nalidixic acid, and flumequine through formation of ternary complex with $\mathrm{Cd}$ (II) [24] and used for determination of barium through formation of ternary complex with 18-crown-6 [25]. Copper was used as a complexing agent for determination of several drugs for example, lincomycin [26], ramipril, perindopril [27] and enalapril maleate [28], lansoprazole and pantoprazole sodium sesquihydrate [29], and risedronate [30].

\section{Experimental}

2.1. Instruments. The absorption spectra for all measurements were carried out using shimadzu recording spectrophotometer UV 1201 equipped with $10 \mathrm{~mm}$ matched quartz cells. Conductometer model 470 portable conductivity/ TDS meter, 25 DEG.C-C10 dip-type cell was used with a cell constant, K cell, of 1.09. Digital analyzer pH meter (USA) was used.

2.2. Reagents and Materials. All chemicals and materials were of analytical grade, and bidistilled water was used throughout the work.

(i) Erythromycin thiocyanate, Erythrocin film tablets labelled to contain erythromycin stearate equivalent to $500 \mathrm{mg}$ erythromycin per tablet (Kahira Pharm. \& Chem.Ind.Co.), and erythrocin pharco powder for oral suspension labelled to contain erythromycin ethylsuccinate equivalent to $200 \mathrm{mg}$ erythromycin to each $5 \mathrm{~mL}$ reconstituted suspension (Pharco Company For Phrmaceuticals, Egypt).

(ii) Clarithromycin, Klarimix tablets labelled to contain $250 \mathrm{mg}$ clarithromycin per tablet, and Klarimix powder for oral suspension labelled to contain $125 \mathrm{mg}$ clarithromycin to each $5 \mathrm{~mL}$ reconstituted suspension (SIGMA Pharmaceutical Industries, Egypt).

(iii) Azithromycin dihydrate, Zithrokan capsules, Azrolid tablets (Amriya For Phrmaceutical Industries, Egypt) labelled to contain $524.1 \mathrm{mg}$ azithromycin dihydrate per capsule/tablet, and Zithrokan powder for oral suspension labelled to contain $200 \mathrm{mg}$ azithromycin to each $5 \mathrm{~mL}$ reconstituted suspension (Hikma Pharma, 6 th of October city, Egypt).

(iv) Rose bengal (Aldrich, Germany) was used as $3 \mathrm{mg} /$ $\mathrm{mL}$ in double-distilled water for the spectrophotometric method. For conductometric method, $3 \times$ $10^{-3} \mathrm{M}$ in double distilled water for (I), in $50 \%(\mathrm{v} / \mathrm{v})$ ethanol for (II), and in 50\% (v/v) methanol for (III).

(v) Copper(II) chloride (El-Nasr chemical pharmaceutical company, Egypt) solution was used as $3 \mathrm{mg} / \mathrm{mL}$ in double-distilled water.

(vi) Glucose, Sucrose, sodium chloride, carboxy methyl cellulose sodium, calcium carbonate, magnesium stearate (El-Nasr chemical pharmaceutical company, Egypt).

All drugs whose purity was found to be $100.12 \%$ according to the reported method [6] were used as received.

\subsection{Preparation of Sample Solutions}

(i) For the spectrophotometric method, solution of $0.5 \mathrm{mg} / \mathrm{mL}$ for (I) and (II) and of $0.2 \mathrm{mg} / \mathrm{mL}$ for (III) was dissolved in low amount of ethanol and completed with double distilled water to the mark.

(ii) For conductometric method, solution of $1 \mathrm{mg} / \mathrm{mL}$ was dissolved in low amount of methanol for (I) and completed with double distilled water to the mark, in $50 \%(\mathrm{v} / \mathrm{v})$ ethanol for (II) and 50\% (v/v) methanol for (III).

\subsection{Recommended Procedures and Calibration Curves}

2.4.1. Spectrophotometric Measurements. Into a series of $60 \mathrm{~mL}$ separating funnels, aliquots of drug solutions equivalent to $1.5-6,0.75-4$, and $0.4-2 \mathrm{mg}$ of erythromycin thiocyanate (I), clarithromycin (II), azithromycin dihydrate (III), respectively, were transferred, then specific volumes of $\mathrm{Cu}$ (II) chloride solution $(3 \mathrm{mg} / \mathrm{mL}$ ) were added followed by specified amounts of rose bengal $(3 \mathrm{mg} / \mathrm{mL})$ and left for 5 minutes in case of Clarithromycin (II) (Table 1). The complex was extracted with $3 \times 3 \mathrm{~mL}$ portions of methylene chloride. 
TABLE 1: Quantitative parameters for the spectrophotometric determination of erythromycin thiocyanate (I), clarithromycin (II), and azithromycin dihydrate (III) with rose bengal copper.

\begin{tabular}{|c|c|c|c|}
\hline Parameter & (I) & (II) & (III) \\
\hline$\lambda \max (\mathrm{nm})$ & 558 & 557 & 560 \\
\hline Beer's law ranges $(\mu \mathrm{g} / \mathrm{mL})$ & $15-60$ & $7.5-40$ & $4-20$ \\
\hline \multicolumn{4}{|l|}{ Regression equation ${ }^{* *}$} \\
\hline Slope $(b)$ & 0.0193 & 0.0209 & 0.0617 \\
\hline Intercept $(a)$ & -0.1413 & -0.022 & -0.1247 \\
\hline Correlation coefficient $\left(r^{2}\right)$ & 0.9999 & 0.9999 & 0.9999 \\
\hline $\mathrm{LOD} \mu \mathrm{g} / \mathrm{mL}$ & 1 & 0.93 & 0.31 \\
\hline $\mathrm{LOQ} \mu \mathrm{g} / \mathrm{mL}$ & 3.04 & 2.8 & 0.95 \\
\hline Ringbom optimum concentration range ( $\mu \mathrm{g} / \mathrm{mL})$ & $20-50$ & $10-35$ & $9-16$ \\
\hline Sandell's sensitivity $\mu \mathrm{g} \cdot \mathrm{cm}^{-2}$ & 0.07 & 0.05 & 0.02 \\
\hline$\varepsilon\left(\times 10^{4}\right) \mathrm{L} \cdot \mathrm{mol}^{-1} \cdot \mathrm{cm}^{-1}$ & 1.12 & 1.47 & 3.78 \\
\hline
\end{tabular}

* Average of three experiments.

${ }^{* *} \mathrm{~A}=a+b c$.

The solutions were vigorously shaken for one minute and the organic layer filtered over anhydrous sodium sulphate into $10 \mathrm{~mL}$ volumetric flasks, then the volumes were completed to $10 \mathrm{~mL}$ with methylene chloride. The absorbances of the colored solutions were measured at 558, 557, and $560 \mathrm{~nm}$ for (I), (II), and (III), respectively, against reagent blank treated similarly (Figure 1). All measurements were made at ambient temperature.

2.4.2. Conductometric Titrations. Aliquot of sample solution containing $1-15 \mathrm{mg}$ of the cited drugs was transferred to a $50 \mathrm{~mL}$ calibrated flask, and volume was made up to the mark using bidistilled water for (I), 50\% (v/v) ethanol for (II), and $50 \%(\mathrm{v} / \mathrm{v})$ methanol for (III). The contents of the calibrated flask were transferred to a beaker, and the conductivity cell was immersed. $3 \times 10^{-3} \mathrm{M}$ rose bengal was used for titration. The conductance was measured subsequently to each addition of reagent solution and, after thorough stirring for two minutes, corrected for dilution effect [31] by means of the following equation, assuming that conductivity is a linear function of dilution

$$
\Omega_{\text {correct }}^{-1}=\Omega_{\mathrm{obs}}^{-1}\left[\frac{\left(v_{1}+v_{2}\right)}{v_{1}}\right],
$$

where $\Omega_{\text {obs }}^{-1}$ is the observed electrolytic conductivity, $v_{1}$ is the initial volume, and $v_{2}$ is the volume of reagent added. A graph of corrected conductivity versus the volume of added titrant was constructed and the endpoint was determined (Figure 7).

\subsection{Procedure for Pharmaceutical Preparations}

2.5.1. For Spectrophotometric Method. The contents of five capsules were removed and weighed accurately. The combined contents were mixed, and a quantity of the powder equivalent to $25 \mathrm{mg}$ for (I) and (II) and equivalent to $10 \mathrm{mg}$ for (III) was extracted with low amount of ethanol in $50 \mathrm{~mL}$ volumetric flask. The volumes were completed to the mark with double-distilled water filtered, and the assay was completed as described under general procedure. The same

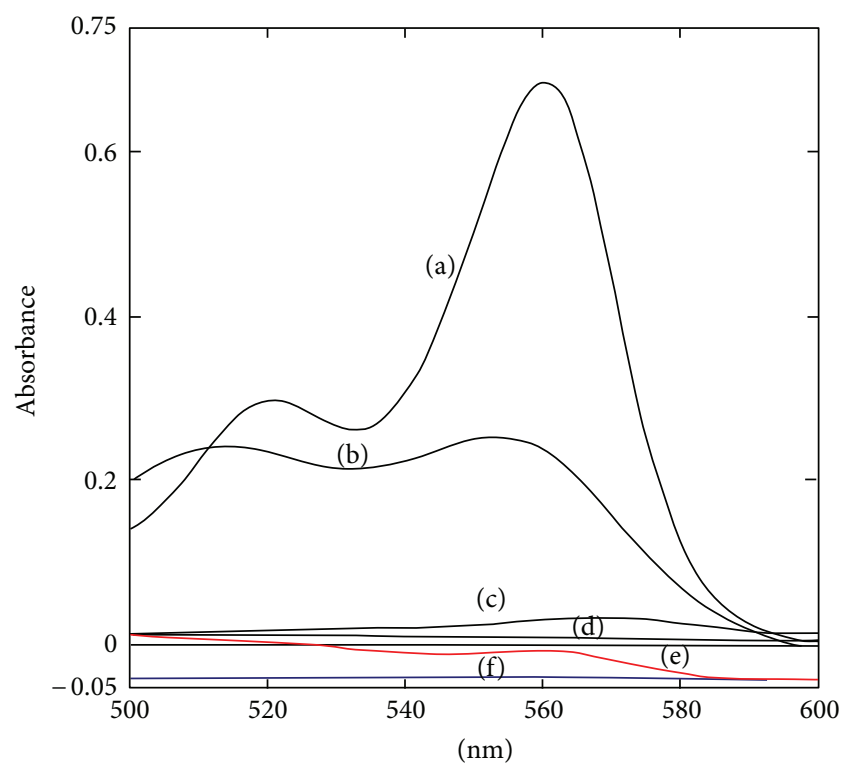

FIGURE 1: Absorption spectra for (a) the reaction of $13 \mu \mathrm{g} / \mathrm{mL}$ azithromycin dihydrate with $0.5 \mathrm{~mL} \mathrm{Cu}(\mathrm{II})$ chloride $0.3 \% \mathrm{w} / \mathrm{v}$ and $0.2 \mathrm{~mL} 0.3 \% \mathrm{w} / \mathrm{v}$ rose bengal, (b) $13 \mu \mathrm{g} / \mathrm{mL}$ azithromycin dihydrate with $0.2 \mathrm{~mL}$ rose bengal $0.3 \% \mathrm{w} / \mathrm{v}$, (c) $13 \mu \mathrm{g} / \mathrm{mL}$ azithromycin dihydrate with $0.5 \mathrm{~mL} \mathrm{Cu}$ (II) chloride $0.3 \% \mathrm{w} / \mathrm{v}$, (d) $0.2 \mathrm{~mL}$ rose bengal $0.3 \% \mathrm{w} / \mathrm{v}$ and $0.5 \mathrm{~mL} \mathrm{Cu}(\mathrm{II})$ chloride $0.3 \% \mathrm{w} / \mathrm{v}$, (e) $0.2 \mathrm{~mL}$ rose bengal $0.3 \% \mathrm{w} / \mathrm{v}$, and (f) $0.5 \mathrm{~mL} \mathrm{Cu}($ II) chloride $0.3 \% \mathrm{w} / \mathrm{v}$.

procedures were followed with tablets taking an accurately weighed amount of ten combined powdered tablets. The same procedures were followed with oral suspension taking an accurately measured volume of the freshly reconstituted oral suspension equivalent to the specified concentration.

2.5.2. For Conductometric Method. The same procedure was followed as in the spectrophotometric method but the quantity of the powder taken from tablets or capsules or the accurately measured volume of the freshly reconstituted oral suspension is equivalent to $100 \mathrm{mg}$ for all drugs and was extracted by least amount of methanol for (I), 50\% (v/v) 
ethanol for (II), and 50\% (v/v) methanol for (III), filtered, and transferred to a $100 \mathrm{~mL}$ volumetric flask, completed to the mark using distilled water for (I), 50\% (v/v) ethanol for (II), and in $50 \%(\mathrm{v} / \mathrm{v})$ methanol for (III) and the assay was completed as described under general procedure.

\section{Results and Discussion}

Optimization of Variables. Ternary complexes have been widely used in spectrophotometric analysis. The absorption spectrum in aqueous medium of rose bengal shows an absorption peak with $\lambda \max 540 \mathrm{~nm}$. Upon addition of any of the three cited drugs to a mixture of $\mathrm{Cu}(\mathrm{II})$ and rose bengal solution, it was found that a pink soluble complex was formed, and the absorbance maximum of $\mathrm{Cu}$ (II) rose bengal originally at $540 \mathrm{~nm}$ was abridged to a shoulder with a new absorption maxima at 558, 557, and $560 \mathrm{~nm}$ for (I), (II), and (III), respectively. The absorption spectrum shows that the ternary complexes formed between rose bengal and copper with the cited drugs have higher values of molar extinction coefficient than the binary complexes for the spectrophotometric method (Figure 1). Investigations were carried out to establish the most favorable conditions for the ternary complex formation for the spectrophotometric method of the cited drugs with rose bengal and copper to achieve maximum color development, and for ion-pair formation for the conductometric method to achieve the endpoint.

\subsection{Conditions for Spectrophotometric Method}

3.1.1. Effect of $p H$. In a trial to elucidate the optimum medium for the quantitative determination of the studied drugs, the effect of different acetate and phosphate buffers of $\mathrm{pH}$ of range 2-10 was examined. It was found that buffer had no effect on the reaction.

3.1.2. Effect of $\mathrm{Cu}$ (II) Chloride Volume. The effect of $\mathrm{Cu}(\mathrm{II})$ chloride volume was also tested by using varying amounts $(0.1-2 \mathrm{~mL})$ of $\mathrm{Cu}$ (II) chloride $(3 \mathrm{mg} / \mathrm{mL})$. The results showed that $0.2 \mathrm{~mL}, 1.5 \mathrm{~mL}$, and $0.5 \mathrm{~mL}$ of $\mathrm{Cu}$ (II) chloride $(3 \mathrm{mg} / \mathrm{mL})$ for (I), (II), and (III), respectively, were sufficient for the production of maximum and reproducible colour intensity (Figure 2).

3.1.3. Effect of Rose Bengal Volume. Highest constant absorbance was obtained on using $1.5 \mathrm{~mL}, 0.5 \mathrm{~mL}$, and $0.2 \mathrm{~mL}$ of rose bengal $(3 \mathrm{mg} / \mathrm{mL})$ for (I), (II), and (III), respectively, (Figure 3).

3.1.4. Effect of Order of Addition. The most suitable sequence was drug, $\mathrm{Cu}$ (II) chloride, and then rose bengal for all drugs for the production of the highest colour intensity, while the other sequences produced lower absorbance values.

3.1.5. Effect of Reaction Time and Stability. Maximum colour intensity was attained immediately for the studied drugs

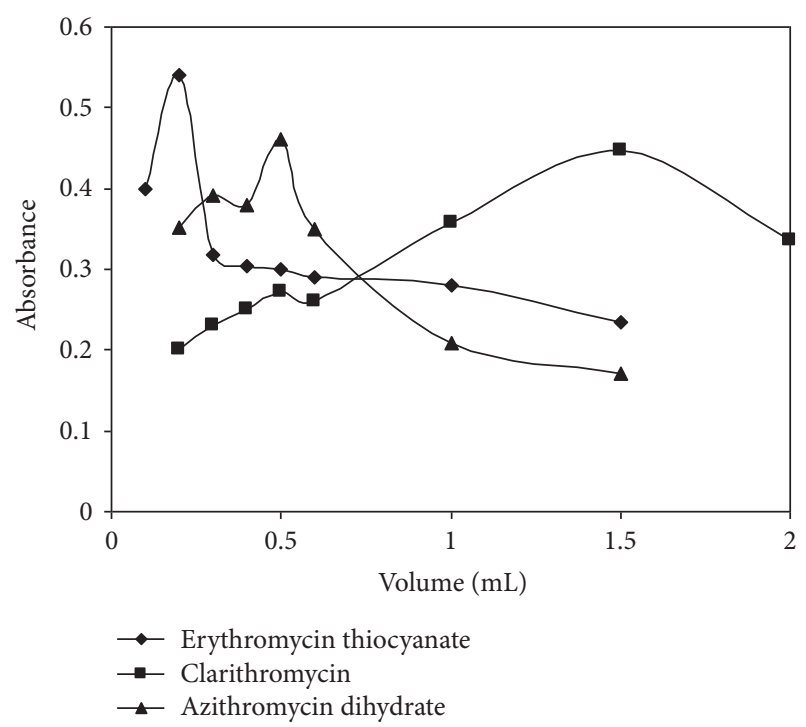

Figure 2: Effect of volume of $0.3 \% \mathrm{w} / \mathrm{v} \mathrm{Cu}(\mathrm{II})$ chloride on the ternary complex formed with $40 \mu \mathrm{g} / \mathrm{mL}$ erythromycin thiocyanate and $1.5 \mathrm{~mL}$ rose bengal $0.3 \% \mathrm{w} / \mathrm{v} ; 25 \mu \mathrm{g} / \mathrm{mL}$ clarithromycin and $0.5 \mathrm{~mL}$ rose bengal $0.3 \% \mathrm{w} / \mathrm{v} ; 13 \mu \mathrm{g} / \mathrm{mL}$ azithromycin dihydrate and $0.2 \mathrm{~mL}$ rose bengal $0.3 \% \mathrm{w} / \mathrm{v}$.

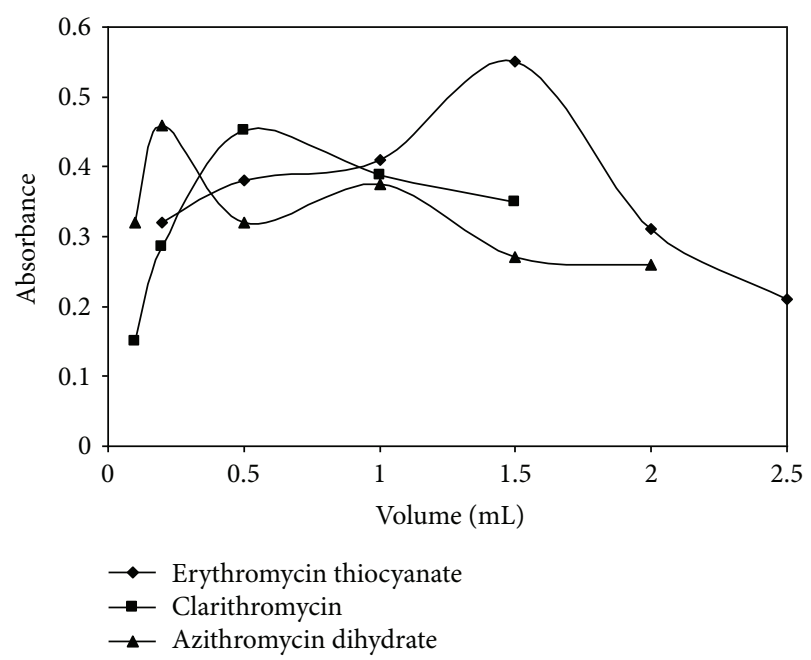

Figure 3: Effect of volume of $0.3 \% \mathrm{w} / \mathrm{v}$ rose bengal on the ternary complex formed with $40 \mu \mathrm{g} / \mathrm{mL}$ erythromycin thiocyanate and $0.2 \mathrm{~mL} \mathrm{Cu}(\mathrm{II})$ chloride $0.3 \% \mathrm{w} / \mathrm{v} ; 25 \mu \mathrm{g} / \mathrm{mL}$ clarithromycin and $1.5 \mathrm{~mL} \mathrm{Cu}(\mathrm{II})$ chloride $0.3 \% \mathrm{w} / \mathrm{v} ; 13 \mu \mathrm{g} / \mathrm{mL}$ azithromycin dihydrate and $0.5 \mathrm{~mL} \mathrm{Cu}(\mathrm{II})$ chloride $0.3 \% \mathrm{w} / \mathrm{v}$.

except for (II); it needs 5 minutes to give complete complexation, and increasing time beyond this had no effect on absorption. The obtained colour was stable for at least 1 hour for all drugs at room temperature $\left(25^{\circ} \mathrm{C} \pm 2\right)$. The formation constants have been calculated by using the molar ratio method [32]. The formation constants $(K f)$ of the reaction product were found to be $7.13 \times 10^{4}, 7.6 \times 10^{5}$, and $1.5 \times$ $10^{6} \mathrm{~L} \cdot \mathrm{mol}^{-1}$ for (I), (II), and (III), respectively. This high value indicates a very stable reaction product. The Gibbs free energy change of the reaction $(\Delta G)$ was also calculated 


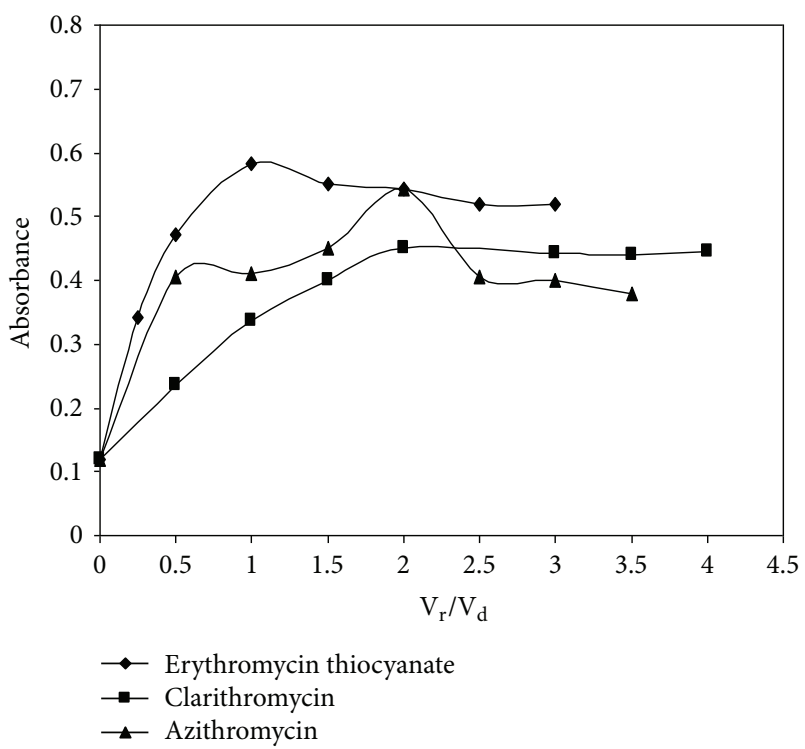

Figure 4: Molar ratio method plot for $2.5 \times 10^{-4} \mathrm{M}$ erythromycin thiocyanate and $2.5 \times 10^{-4} \mathrm{M} \mathrm{Cu}(\mathrm{II})$ chloride in presence of excess rose bengal $(1.5 \mathrm{~mL} 0.3 \%) ; 2.5 \times 10^{-4} \mathrm{M}$ clarithromycin and $2.5 \times$ $10^{-4} \mathrm{M} \mathrm{Cu}$ (II) chloride in presence of excess rose bengal $(0.5 \mathrm{~mL}$ $0.3 \%) ; 1.25 \times 10^{-4} \mathrm{M}$ azithromycin dihydrate and $1.25 \times 10^{-4} \mathrm{M}$ $\mathrm{Cu}(\mathrm{II})$ chloride in presence of excess rose bengal $(0.2 \mathrm{~mL} 0.3 \%)$ $\mathrm{V}_{\mathrm{R}}=\mathrm{Cu}(\mathrm{II})$ chloride and $\mathrm{V}_{\mathrm{d}}=$ Drug.

and was found to be $-2.78 \times 10^{4},-3.35 \times 10^{4}$, and -3.52 $\times 10^{4} \mathrm{~K} \cdot \mathrm{J} \cdot \mathrm{mole}^{-1}$ for (I), (II), and (III), respectively. The negative value of $\Delta G$ points out to the spontaneous nature of the reaction [33].

3.1.6. Effect of the Extraction Time and Number of Extractions. Shaking the reaction mixture with the extracting organic solvent is required for complete extraction of the ternary complex formed. It was found that 1 minute is enough time for complete colour extraction. Complete extraction was attained by triple extraction with $3 \times 3 \mathrm{~mL}$ of methylene chloride for all drugs.

3.1.7. Effect of Solvent. Many organic solvents were tried to extract the ternary complexes formed (chloroform, methylene chloride, ethylene chloride, benzene, toluene, and ethyl acetate). The results obtained indicated that methylene chloride is the appropriate solvent for extraction for all drugs.

\subsubsection{Determination of Stoichiometric Balance Using Molar} Ratio Method [34]. The reaction stoichiometry between erythromycin thiocyanate (I), clarithromycin (II), azithromycin dihydrate (III) with $\mathrm{Cu}$ (II) chloride and rose bengal was studied by molar ratio method using an equimolar $\left(2.5 \times 10^{-4} \mathrm{M}\right)$ solution of erythromycin thiocyanate (I), clarithromycin (II), and $\left(1.25 \times 10^{-4} \mathrm{M}\right)$ solutions of azithromycin dihydrate (III), $\mathrm{Cu}$ (II) chloride, and rose bengal of the same molarities. The obtained results showed that the composition of the ternary complexes was $1: 1: 2$ for erythromycin thiocyanate (I) and

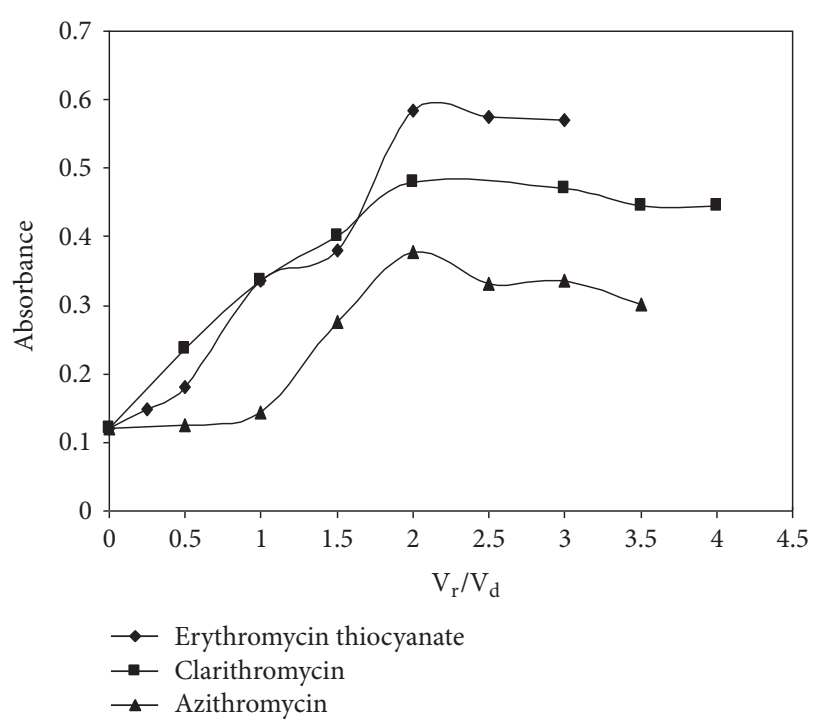

FIGURE 5: Molar ratio method plot for $2.5 \times 10^{-4} \mathrm{M}$ erythromycin thiocyanate with $2.5 \times 10^{-4} \mathrm{M}$ rose bengal in presence of excess $\mathrm{Cu}$ (II) chloride $(0.2 \mathrm{~mL} 0.3 \%) ; 2.5 \times 10^{-4} \mathrm{M}$ clarithromycin with $2.5 \times 10^{-4} \mathrm{M}$ rose bengal in presence of excess $\mathrm{Cu}(\mathrm{II})$ chloride $(1.5 \mathrm{~mL}$ $0.3 \%) ; 1.25 \times 10^{-4} \mathrm{M}$ azithromycin dihydrate with $1.25 \times 10^{-4} \mathrm{M}$ rose bengal in presence of excess $\mathrm{Cu}(\mathrm{II})$ chloride $(0.5 \mathrm{~mL} 0.3 \%) . \mathrm{V}_{\mathrm{r}}=$ rose bengal and $\mathrm{V}_{\mathrm{d}}=$ Drug.

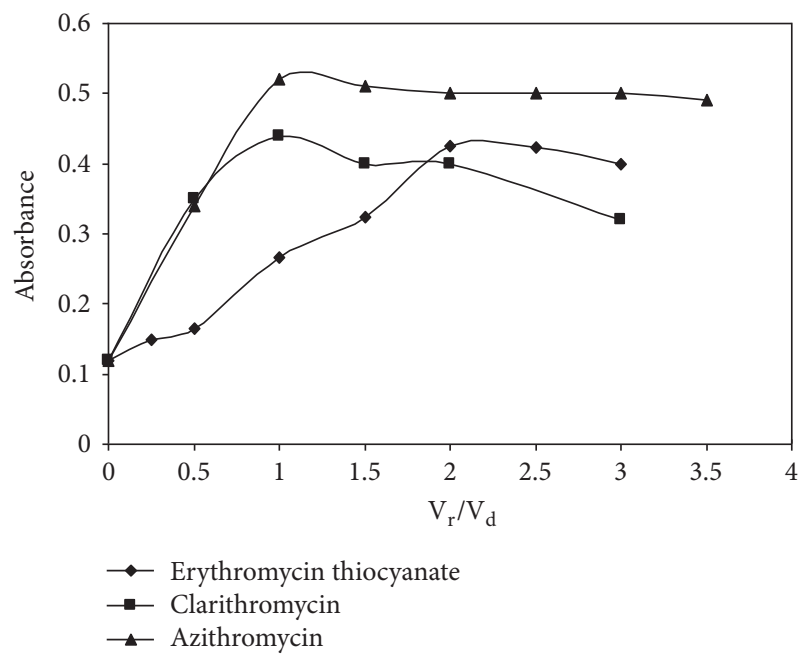

FIGURE 6: Molar ratio method plot for $2.5 \times 10^{-4} \mathrm{M}$ rose bengal with $2.5 \times 10^{-4} \mathrm{M} \mathrm{Cu}(\mathrm{II})$ chloride in presence of excess erythromycin thiocyanate $\left(30 \mu \mathrm{g} \cdot \mathrm{mL}^{-1}\right) ; 2.5 \times 10^{-4} \mathrm{M}$ rose bengal with $2.5 \times 10^{-4} \mathrm{M} \mathrm{Cu}(\mathrm{II})$ chloride in presence of excess clarithromycin $\left(30 \mu \mathrm{g} \cdot \mathrm{mL}^{-1}\right) ; 1.25 \times 10^{-4} \mathrm{M}$ rose bengal with $1.25 \times 10^{-4} \mathrm{M} \mathrm{Cu}(\mathrm{II})$ chloride in presence of excess azithromycin dihydrate $\left(10 \mu \mathrm{g} \cdot \mathrm{mL}^{-1}\right)$. $\mathrm{V}_{\mathrm{r}}$ = rose bengal and $\mathrm{V}_{\mathrm{R}}=\mathrm{Cu}(\mathrm{II})$ chloride.

$1: 2: 2$ for clarithromycin (II) and azithromycin dihydrate (III) : $\mathrm{Cu}$ (II) chloride: rose bengal (Figures 4, 5, and 6).

Scheme 1 illustrates the mechanism of the reaction of clarithromycin, rose bengal and copper(II) chloride. The lactone ring in clarithromycin is substituted with a number of hydroxyl functional groups. These groups are positioned in suitable configuration for interaction with metal ions. So, 


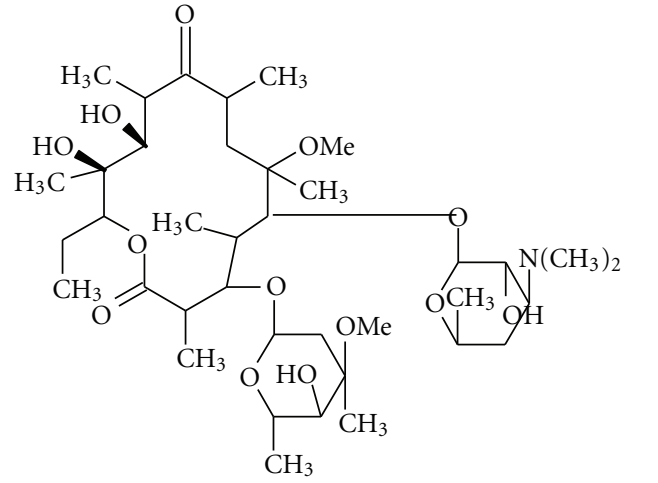

Clarithromycin<smiles>O=C([O-])c1c(Cl)c(Cl)c(Cl)c(Cl)c1-c1c2cc(I)c(=O)c(I)c-2oc2c(I)c([O-])c(I)cc12</smiles>

Rose bengal

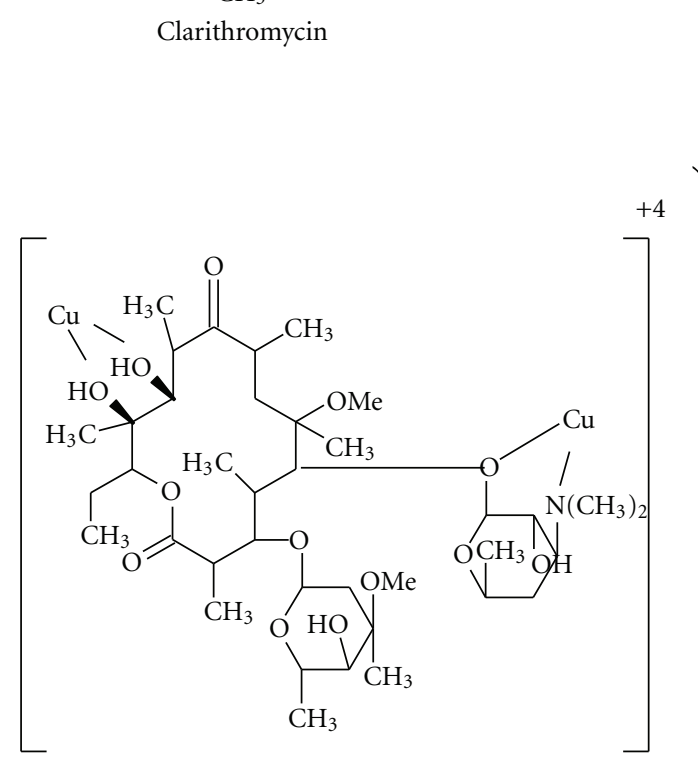<smiles>CCCCC</smiles>

Scheme 1: Proposal Mechanism for the reaction between clarithromycin, rose bengal and copper(II) chloride. clarithromycin-Cu-rose bengal complex.

copper cation forms a chelate with the lone pair of electrons of the two hydroxyl groups at $\mathrm{C}_{11}$ and $\mathrm{C}_{12}$. Also copper can form a chelate with the lone pair of electrons of the tertiary amine group nitrogen and the oxygen of the $\beta$-glycosidic linkage. So, the azithromycin-copper chelate bears an overall positive charge of the original two metal ions, that is, four positive charges. This cationic complex associates with two molecules of rose bengal anions to form the ternary complex.

\subsection{Conditions for Conductometric Method. Investigations} were carried out to establish the most suitable conditions for the ion associates formation of the cited drugs with rose bengal to attain sharp endpoint. The optimum conditions for performing the titration in a quantitative manner were elucidated as described later.

3.2.1. Reaction Medium. Titrations in different media were attempted to obtain the best results. Preliminary experiments were in:

(i) aqueous drug solution for (I) only (prepared by dissolving $100 \mathrm{mg}$ drug in $2 \mathrm{~mL}$ methanol then completing to $100 \mathrm{~mL}$ with bidistilled water) with aqueous reagent solution,

(ii) ethanol drug solution with ethanol reagent solution,

(iii) drug solution with reagent solution, both in ethanolwater $(50 \%, \mathrm{v} / \mathrm{v})$ mixture,

(iv) methanol drug solution with methanol reagent solution (except for (II) as it is insoluble in methanol),

(v) drug solution with reagent solution, both in methanol-water mixture (50\% v/v) (except for (II) as it is insoluble in methanol),

(vi) drug solution with reagent solution, both in acetonewater $(50 \% \mathrm{v} / \mathrm{v})$ mixture.

Preliminary experiments showed that procedure in aqueous media was the most suitable for successful results for (I), $50 \%(\mathrm{v} / \mathrm{v})$ ethanol for (II), and 50\% (v/v) methanol for (III).

3.2.2. Reagent's Concentration. Different concentrations of rose bengal solution were tried ranging from $2 \times 10^{-2}$ to $5 \times 10^{-4}$ molar solutions. The optimum concentration of the reagent was $3 \times 10^{-3} \mathrm{M}$ in titration of the studied drug to 


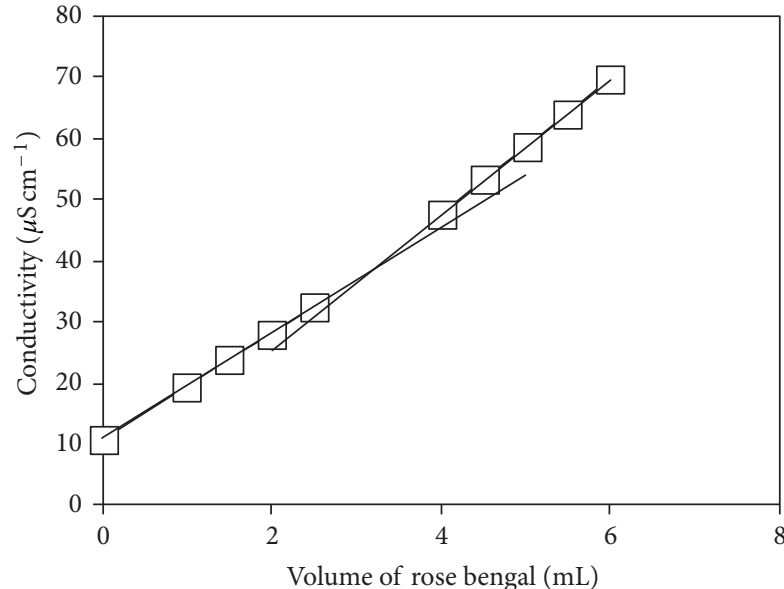

FIGURE 7: Conductometric titration curve of $15 \mathrm{mg}$ clarithromycin versus $3 \times 10^{3} \mathrm{M}$ rose bengal.

achieve a constant and highly stable conductance reading within 1-2 min of mixing. Concentrations less than these limits led to unstable readings, and more time was needed to obtain constant conductance values.

Representative titration curve is shown in (Figure 7). Two straight lines are obtained, intersecting at the endpoint; the first branch ascending, and the second has conductance values that would slightly increase after the equivalence point. The increase of conductance may be attributed to the formation of ion pair in solution as a result of the complexation reaction. After the end-point, the titration curves indicate a slightly increased value of conductance, despite the excess of the reagent. This may be due to further ionic condensation, leading to species of lower mobility.

The conductometric titrations of different volumes of $3 \times 10^{-3} \mathrm{M}$ rose bengal solution were performed. The results show an obvious maximum in the conductance curve at drugreagent molar ratio of $2: 1$ for (I) and (II) and $1: 1$ for (III). The reactions may be represented by (for (I))

$$
[\mathrm{RB}]^{-2}+2\left[\text { Eryth } \mathrm{N}(\mathrm{Me})_{2}\right] \stackrel{\mathrm{H}^{+}}{\longrightarrow}[\mathrm{RB}]^{-2}\left[\text { Eryth } \mathrm{NH}(\mathrm{Me})_{2}\right]_{2}^{+2}
$$

where $[\mathrm{RB}]^{-2}$ rose bengal anion $\left[\right.$ Eryth $\mathrm{N}(\mathrm{Me})_{2}$ ] erythromycin thiocyanate $\left[\text { ErythNH }(\mathrm{Me})_{2}\right]^{+2}$ protonated erythromycin thiocyanate.

Erythromycin thiocyanate tertiary amine nitrogen is protonated, so attraction occurs between it and rose bengal anion forming ion-pair complex.

The conductance measured before the addition of the titrant (volume of rose bengal equals zero) is mainly due to the hydrogen ions mobility. These hydrogen ions result from two sources:

(1) the active methylene group in the drug structure as in Scheme 2 which has the ability to make self protonation to the drug

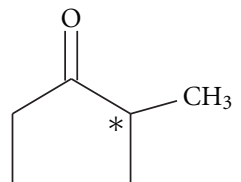

Scheme 2: ${ }^{*}$ The active methylene group in macrolide structure.

(2) the protons coming from the alcohols used in solubility, as these alcohols have certain acidity character so can protonate the amino group in drug structure.

So, there is no need for acidic buffer use for drug protonation. It was expected that the conductance values would remain constant or slightly increase after the equivalence point. However, the conductance of the solution decreased. This may be due to interaction of the protons available in the titration medium with the added reagent. The results from the conductometic titrations are summarized in Table 4 . The data show that accurate results were obtained with good recoveries and low standard deviation values. The optimum concentration ranges for determination of the cited drugs were in the range of $1-15 \mathrm{mg} \mathrm{mL}^{-1}$ for all drugs. At such ranges, sharp inflections (Figure 7) and stable conductance reading were obtained.

\subsection{Method Validation}

\subsubsection{For the Spectrophotometric Method}

Linearity. Under the optimum conditions described, standard calibration curves for erythromycin thiocyanate (I), clarithromycin (II), and azithromycin dihydrate (III) with rose bengal and copper were constructed by plotting absorbance against concentration. Conformity with Beer's law was evident in the concentration range of the final dilution cited in Table 1. Beer's law holds over the concentration ranges of $15-60,7.5-40$, and $4-20 \mu \mathrm{g} \cdot \mathrm{mL}^{-1}$ for (I), (II), and (III), respectively. The linear regression equation for each drug was listed in Table 1. The correlation coefficient was 0.9999 indicating good linearity over the working concentration range.

Sensitivity. The detection limit (LOD) for the proposed method was calculated using the following equation according to the ICH [35]:

$$
\mathrm{LOD}=3.3 \frac{\sigma}{\mathrm{S}},
$$

where $\sigma=$ the standard deviation of replicate blank responses (under the same conditions as for sample analysis), and $\mathrm{S}=$ the slope of the calibration curve.

The limits of quantification, $\mathrm{LOQ}$, is defined as

$$
\text { LOQ }=10 \frac{\sigma}{\mathrm{S}} \text {. }
$$




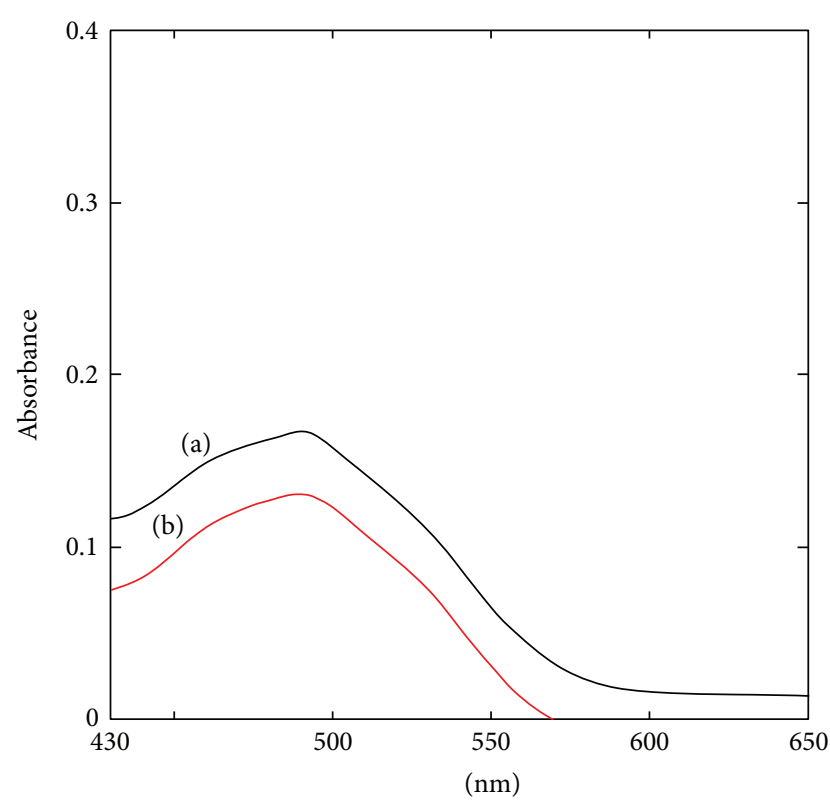

FIgURE 8: Absorption spectra of (a) $2.5 \times 10^{-2}$ M glucose with $1.5 \mathrm{~mL}$ $\mathrm{Cu}$ (II) chloride $0.3 \% \mathrm{w} / \mathrm{v}$ and $0.5 \mathrm{~mL} 0.3 \% \mathrm{w} / \mathrm{v}$ rose bengal, (b) $5 \times$ $10^{-2} \mathrm{M}$ sucrose with $1.5 \mathrm{~mL} \mathrm{Cu(II)}$ chloride $0.3 \% \mathrm{w} / \mathrm{v}$ and $0.5 \mathrm{~mL}$ $0.3 \% \mathrm{w} / \mathrm{v}$ rose bengal.

According to the previous equations, the LODs and LOQs were calculated as in Table 1 . Their values confirm the sensitivity of the proposed method.

Accuracy and Precision. In order to determine the accuracy and precision of the proposed method, solutions containing one concentration of each drug were prepared and analysed in seven replicates. The relative standard deviation (RSD\%) as precision and percentage relative error (Er\%) as accuracy of the suggested method were calculated at $95 \%$ confidence levels and can be considered satisfactory. The percentage relative error was calculated according the following equation:

$$
\text { Er\% }=\left[\frac{\text { found }- \text { added }}{\text { added }}\right] \times 100 \text {. }
$$

The inter- and intraday precisions and accuracy results are shown in Table 5. The analytical results for accuracy and precision show that the proposed method has good repeatability and reproducibility.

Interference. The effect of presence of common excipients such as glucose, sucrose, sodium chloride, carboxy methyl cellulose sodium, calcium carbonate, and magnesium stearate was studied. Table 6 presents the results of determination of clarithromycin as a representative example using the proposed procedure in the presence of aforementioned ingredients. The tolerance ratio was defined as the concentration which gave an error of $\pm 3.0 \%$ in the determination of drugs. Results indicate that the tolerance ratio of drug excipient, $(\mathrm{M}: \mathrm{M})$, is $1: 50$ for glucose and $1: 100$ for sucrose. While there were no interference from the presence of sodium chloride, carboxy methyl cellulose sodium, calcium carbonate, and magnesium stearate. Interference due to glucose and sucrose was further investigated by studying their reaction with $\mathrm{Cu}(\mathrm{II})$ chloride and rose bengal. The study revealed that no interference could be observed at $557 \mathrm{~nm}$, and an interaction product was obtained at $\lambda \max 498$ in tolerance ratios $1: 1$ and $1: 10$ for glucose and $1: 1,1: 10$, $1: 50$ for sucrose. However, interference starts to appear at $\lambda \max 557$ upon using 50 times, 100 -fold excess of the molar concentration of clarithromycin for glucose and sucrose, respectively, as shown in Figure 8.

3.3.2. For the Conductometric Method. In order to address the validity of the proposed method, statistical analysis of the data obtained from its application on the cited drugs in the pure form and in formulations was performed. The results revealed in Tables 5 and 6 showed that the proposed method is satisfactorily accurate, precise, and reproducible over a concentration range of $1-15 \mathrm{mg}$. Results for the determination of the studied drugs using the previously mentioned method were compared with results from reported one [6], Table 7.

3.4. Analytical Applications. The proposed methods were applied to determine the studied drugs in their pharmaceutical dosage forms. Satisfactory results were obtained. The recovery of each drug was calculated by comparing the concentration obtained from the spiked mixtures with those of the drug. The results of analysis of the commercial dosage forms and the recovery study are shown in Tables 2, 3, and 4. The results obtained were compared with the reported method [6]. No significant differences were found between the proposed methods and reported method. Statistical comparison of the results was performed using Student's $t$ test and variance ratio $F$-test at $95 \%$ confidence level (Table 7).

\section{Conclusions}

The proposed methods are advantageous when compared to many of the reported spectrophotometric methods in having higher sensitivity. The data given previously reveal that the proposed methods are simple, accurate, and sensitive with good precision and accuracy. With these methods, one can do the analysis at low cost without losing accuracy. No interference from excipients was encountered. Also, In comparison with the chromatographic methods, the proposed methods are advantageous as HPLC and GLC are not available especially in developing countries, and they require complex and expensive equipment, intensive sample preparation, and personnel skilled in chromatographic techniques. So, the proposed methods can be used as alternative methods to the reported ones for the routine determination of erythromycin thiocyanate (I), clarithromycin (II), azithromycin dihydrate (III) in the pure form and in pharmaceutical formulations depending upon the availability of chemicals and the equipment. 


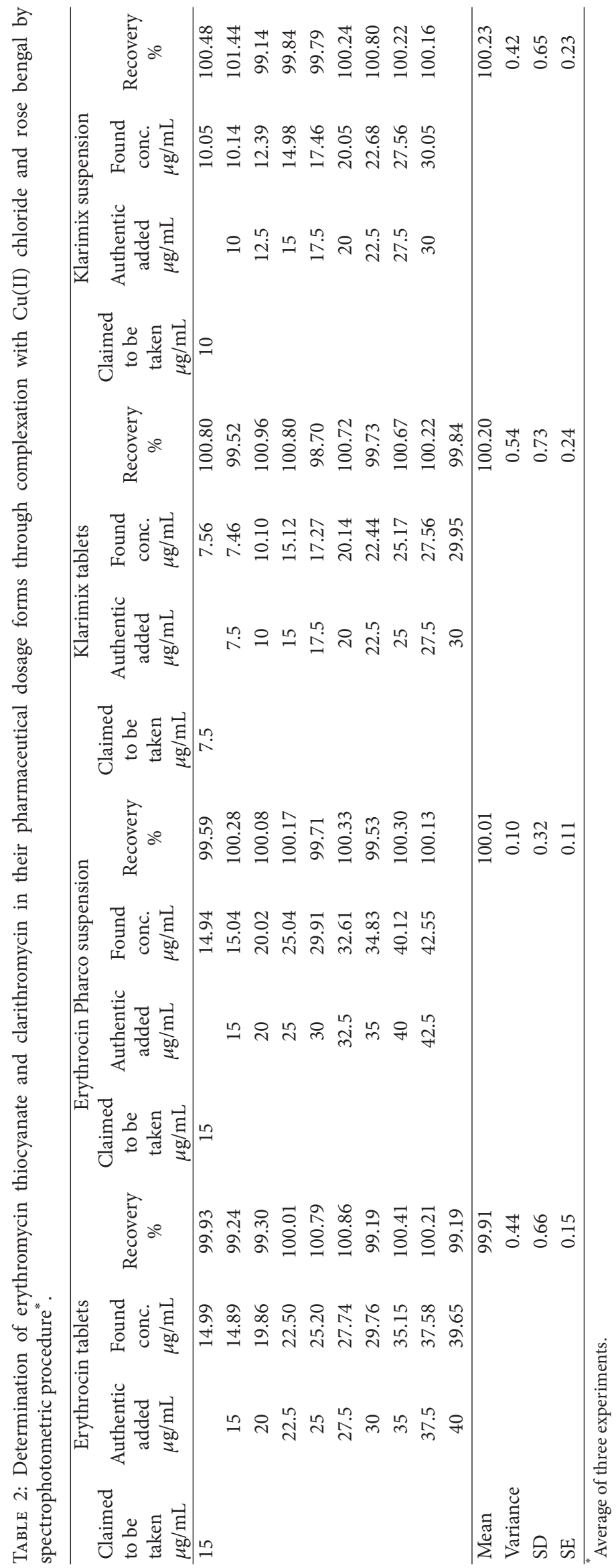




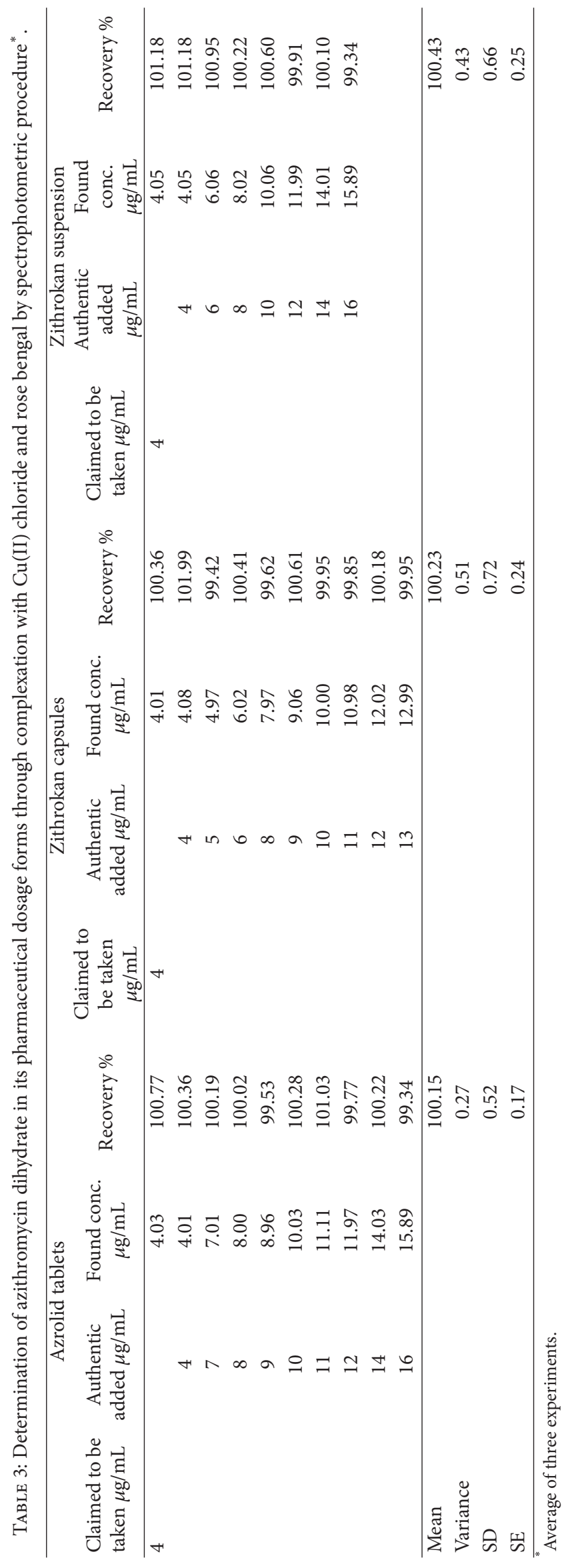


TABLE 4: Application of the proposed conductometric method to the determination of erythromycin thiocyanate in dosage forms* .

\begin{tabular}{|c|c|c|c|c|c|}
\hline \multicolumn{3}{|c|}{ Erythrocin tablets } & \multicolumn{3}{|c|}{ Erythrocin Pharco suspension } \\
\hline Taken (mg) & Found (mg) & Recovery \% & Taken (mg) & Found (mg) & Recovery \% \\
\hline 3 & 3.05 & 101.58 & 2 & 2 & 100 \\
\hline 4 & 4 & 100 & 4 & 4.05 & 101.19 \\
\hline 6 & 6.07 & 101.19 & 7 & 7.05 & 100.68 \\
\hline 8 & 8.1 & 101.19 & 8 & 8.05 & 100.60 \\
\hline 10 & 10 & 100 & 12 & 11.90 & 99.20 \\
\hline 12 & 11.91 & 99.21 & 14 & 13.95 & 99.66 \\
\hline 14 & 14.05 & 100.34 & & & \\
\hline Mean & & 100.50 & & & 100.22 \\
\hline $\mathrm{SD}$ & & 0.85 & & & 0.73 \\
\hline SE & & 0.32 & & & 0.30 \\
\hline RSD & & 0.84 & & & 0.73 \\
\hline Variance & & 0.72 & & & 0.54 \\
\hline
\end{tabular}

Mean of three different experiments.

TABLE 5: The intraday and interday precision and accuracy data for the studied drugs using the spectrophotometric method.

\begin{tabular}{|c|c|c|c|c|c|c|c|c|c|c|}
\hline \multicolumn{6}{|c|}{ Intraday } & \multicolumn{5}{|c|}{ Interday } \\
\hline Drug & $\begin{array}{c}\text { Taken } \\
\left(\mu \mathrm{g} \mathrm{mL}^{-1}\right)\end{array}$ & $\begin{array}{c}\text { Found } \\
\left(\mu \mathrm{g} \mathrm{mL}^{-1}\right)^{\mathrm{a}}\end{array}$ & Recovery \% & $\begin{array}{c}\text { Precision } \\
\text { RSD \% }\end{array}$ & $\begin{array}{c}\text { Accuracy } \\
\text { Er } \%{ }^{c}\end{array}$ & $\begin{array}{c}\text { Taken } \\
\left(\mu \mathrm{g} \mathrm{mL}^{-1}\right)\end{array}$ & $\begin{array}{c}\text { Found } \\
\left(\mu \mathrm{g} \mathrm{mL}^{-1}\right)^{\mathrm{a}}\end{array}$ & Recovery \% & $\begin{array}{c}\text { Precision } \\
\text { RSD \% }\end{array}$ & $\begin{array}{c}\text { Accuracy } \\
\operatorname{Er} \%^{\mathrm{c}}\end{array}$ \\
\hline (I) & 50 & 50.28 & 100.56 & 0.29 & 0.56 & 50 & 50.34 & 100.68 & 0.39 & 0.68 \\
\hline (II) & 30 & 30.33 & 101.09 & 0.56 & 1.09 & 30 & 30.17 & 100.57 & 0.46 & 0.57 \\
\hline (III) & 16 & 15.99 & 99.95 & 0.19 & -0.05 & 16 & 16.01 & 100.07 & 0.25 & 0.07 \\
\hline
\end{tabular}

average of seven determinations.

${ }^{\mathrm{b}} \mathrm{RSD} \%$, percentage relative standard deviation.

${ }^{\mathrm{c}} \mathrm{Er} \%$, percentage relative error.

TABLE 6: Analysis of clarithromycin $28 \mu \mathrm{g} \mathrm{mL}^{-1}\left(5 \times 10^{-4} \mathrm{M}\right)$ by the spectrophotometric method in the presence of some common excipients.

\begin{tabular}{lcccc}
\hline Tolerance molar ratio $(\mathrm{M}: \mathrm{M})^{*}$ & Glucose & Sucrose & $\begin{array}{c}\text { Carboxy methyl cellulose sodium } \\
\text { Recovery \%** }\end{array}$ & Sodium chloride \\
\hline $1: 1$ & 101.24 & 101.07 & 100.89 & 99.82 \\
$1: 10$ & 100.36 & 101.24 & 99.11 & 99.82 \\
$1: 50$ & 115.45 & 102.13 & 100.35 & 99.47 \\
$1: 100$ & 106.57 & 107.46 & 98.22 & 99.29 \\
\hline
\end{tabular}

Drug: excipient.

${ }^{* *}$ Mean of three determinations.

TABLE 7: Determination of the studied drugs by the proposed spectrophotometric and conductmetric methods compared with the reported method [6].

\begin{tabular}{|c|c|c|c|}
\hline & (I) & (II) & (III) \\
\hline \multicolumn{4}{|c|}{ Spectrophotometric method } \\
\hline Mean \pm R.S.D. & $100.05 \pm 0.54$ & $100.01 \pm 0.47$ & $99.87 \pm 0.50$ \\
\hline Variance & 0.29 & 0.22 & 0.25 \\
\hline Student's $t$-test & $0.05(2.17)^{*}$ & $0.4(1.31)^{*}$ & $0.06(2.16)^{*}$ \\
\hline$F$-test & $2.38(4.28)^{*}$ & $3.91(3.60)^{*}$ & $2.68(3.89)^{*}$ \\
\hline$n$ & 7 & 9 & 9 \\
\hline \multicolumn{4}{|c|}{ Conductometric method } \\
\hline Mean \pm R.S.D. & $100.66 \pm 0.93$ & $100.65 \pm 0.63$ & $100.62 \pm 0.62$ \\
\hline Variance & 0.87 & 0.40 & 0.38 \\
\hline Student's $t$-test & $1.31(2.17)^{*}$ & $1.13(2.17)^{*}$ & $2.10(2.228)^{*}$ \\
\hline$F$-test & $1.26(3.87)^{*}$ & $2.15(3.97)^{*}$ & $1.76(8.05)^{*}$ \\
\hline$n$ & 7 & 6 & 6 \\
\hline \multicolumn{4}{|c|}{ Reported method [6] } \\
\hline Mean \pm R.S.D. & $100.04 \pm 0.83$ & $100.15 \pm 0.93$ & $99.89 \pm 0.82$ \\
\hline Variance & 0.69 & 0.86 & 0.67 \\
\hline Student's $t$-test & - & - & - \\
\hline$F$-test & - & - & - \\
\hline$n$ & 7 & 8 & 6 \\
\hline
\end{tabular}

"The figures in parenthesis are the theoretical values for $t$ and $F$-tests $(P<0.05)$. 


\section{Acknowledgments}

The authors wish to express their great thanks to Dr. Soad Selim Abd El Hay and Dr. Omnia Ahmed Emam Ismaiel at the Analytical Chemistry Department, Zagazig University, for their great help and advices during this work. Also, they would like to point out that the authors do not have any conflict of interests with any company or institution.

\section{References}

[1] S. C. Sweetman, Martindale, the Complete Drug Reference, Pharmaceutical Press, London, UK, 35th edition, 2007.

[2] S. Omura, Macrolide Antibiotics, Academic Press, London, UK, 1984.

[3] J. N. Delgado and W. A. Remers, Wilson and Gisvold's Textbook of Organic Medecinal and Pharmaceutical Chemistry, J. B. Lippincott Company, London, UK, 1998.

[4] H. A. Krisr, Progress in Medicinal Chemistry, vol. 30 of Edited by G. P. Ellis and D. K. Luscombe, 1993.

[5] British Pharmacopoeia, Her Majesty's Stationery Office, London, UK, 2007.

[6] M. I. Walash, M. S. Rizk, M. I. Eid, and M. E. Fathy, "Spectrophotometric determination of four macrolide antibiotics in pharmaceutical formulations and biological fluids via binary complex formation with eosin and spectrophotometry," Journal of AOAC International, vol. 90, no. 6, pp. 1579-1587, 2007.

[7] J. Shah, M. R. Jan, and S. Manzoor, "Extractive spectrophotometric methods for determination of clarithromycin in pharmaceutical formulations using bromothymol blue and cresol red," Journal of the Chinese Chemical Society, vol. 55, no. 5, pp. 1107-1112, 2008.

[8] C. E. R. De Paula, V. G. K. Almeida, and R. J. Cassella, "Novel spectrophotometric method for the determination of azithromycin in pharmaceutical formulations based on its charge transfer reaction with quinalizarin," Journal of the Brazilian Chemical Society, vol. 21, no. 9, pp. 1664-1671, 2010.

[9] S. Ashour and R. Bayram, "Novel spectrophotometric method for determination of some macrolide antibiotics in pharmaceutical formulations using 1, 2-naphthoquinone-4-sulphonate," Spectrochim Acta Part A, vol. 99, pp. 74-80, 2012.

[10] S. D. Magar, A. P. Tupe, P. Y. Pawar, and B. Y. Mane, "Simultaneous spectrophotometric estimation of cefixime and azithrhomycin in tablet dosage form," Current Pharma Research, vol. 2, no. 3, pp. 535-538, 2012.

[11] P. Y. Khashaba, "Spectrofluorimetric analysis of certain macrolide antibiotics in bulk and pharmaceutical formulations," Journal of Pharmaceutical and Biomedical Analysis, vol. 27, no. 6, pp. 923-932, 2002.

[12] N. El-Rabbat, H. F. Askal, P. Y. Khashaba, and N. N. Attia, "A validated spectrofluorometric assay for the determination of certain macrolide antibiotics in pharmaceutical formulations and spiked biological fluids," Journal of AOAC International, vol. 89, no. 5, pp. 1276-1287, 2006.

[13] C. L. Flurer, "Analysis of macrolide antibiotics by capillary electrophoresis," Electrophoresis, vol. 17, no. 2, pp. 359-366, 1996.

[14] A. K. Lalloo, S. C. Chattaraj, and I. Kanfer, "Development of a capillary electrophoretic method for the separation of the macrolide antibiotics, erythromycin, josamycin and oleandomycin," Journal of Chromatography B, vol. 704, no. 1-2, pp. 333-341, 1997.
[15] M. Hedenmo and B. M. Eriksson, "Liquid chromatographic determination of the macrolide antibiotics roxithromycin and clarithromycin in plasma by automated solid-phase extraction and electrochemical detection," Journal of Chromatography A, vol. 692, no. 1-2, pp. 161-166, 1995.

[16] M. Dubois, D. Fluchard, E. Sior, and P. Delahaut, "Identification and quantification of five macrolide antibiotics in several tissues, eggs and milk by liquid chromatography-electrospray tandem mass spectrometry," Journal of Chromatography B, vol. 753, no. 2, pp. 189-202, 2001.

[17] R. V. S. Nirogi, V. N. Kandikere, M. Shukla et al., "Sensitive and selective liquid chromatography-tandem mass spectrometry method for the quantification of azithromycin in human plasma," Analytica Chimica Acta, vol. 553, no. 1-2, pp. 1-8, 2005.

[18] O. A. E. M. Farghaly and N. A. L. Mohamed, "Voltammetric determination of azithromycin at the carbon paste electrode," Talanta, vol. 62, no. 3, pp. 531-538, 2004.

[19] J. A. Bernabéu, M. A. Camacho, M. E. Gil-Alegre, V. Ruz, and A. I. Torres-Suárez, "Microbiological bioassay of erythromycin thiocyanate: optimisation and validation," Journal of Pharmaceutical and Biomedical Analysis, vol. 21, no. 2, pp. 347-353, 1999.

[20] H. R. N. Salgado and A. F. F. Roncari, "Microbiological assay for the determination of azithromycin in ophthalmic solutions," Yaoxue Xuebao, vol. 40, no. 6, pp. 544-549, 2005.

[21] A. S. Amin and M. M. El-Henawee, "Colorimetric method for the simultaneous determination of chlorphenoxamine hydrochloride and anhydrous caffeine in pure and dosage forms with rose bengal," Mikrochimica Acta, vol. 118, no. 3-4, pp. 177-183, 1995.

[22] F. M. Abdel-Gawad, "Spectrophotometric determination of oxybuprocaine hydrochloride with halofluorescein derivatives," Farmaco, vol. 50, no. 3, pp. 197-200, 1995.

[23] A. S. Amin, "Spectrophotometric and conductometric determination of clindamycin hydrochloride in pure form and in pharmaceutical preparations," Analusis, vol. 23, no. 8, pp. 415-417, 1995.

[24] S. M. Amer, Z. El-Sherif, and M. M. Amer, "Spectrophotometric determination of isoniazid, nalidixic acid and flumequine through ternary complex-formation with $\mathrm{Cd}$ (II) and rose bengal," Egyptian Journal of Pharmaceutical Sciences, vol. 35, no. 1-6, pp. 627-642, 1994.

[25] H. Parham and A. G. Fazeli, "Extraction-spectrophotometric determination of trace amounts of barium by 18-crown- 6 and rose bengal," Analytical Sciences, vol. 16, no. 6, pp. 575-577, 2000.

[26] M. A. El Ries, "Spectrophotometric and indirect determination of lincomycin by atomic absorption spectroscopy," Analytical Letters, vol. 27, no. 8, pp. 1517-1531, 1994.

[27] H. E. Abdellatef, M. M. Ayad, and E. A. Taha, "Spectrophotometric and atomic absorption spectrometric determination of ramipril and perindopril through ternary complex formation with eosin and $\mathrm{Cu}(\mathrm{II})$," Journal of Pharmaceutical and Biomedical Analysis, vol. 18, no. 6, pp. 1021-1027, 1999.

[28] M. M. Ayad, A. A. Shalaby, H. E. Abdellatef, and M. M. Hosny, "Spectrophotometric and AAS determination of ramipril and enalapril through ternary complex formation," Journal of Pharmaceutical and Biomedical Analysis, vol. 28, no. 2, pp. 311-321, 2002. 
[29] A. A. M. Moustafa, "Spectrophotometric methods for the determination of lansoprazole and pantoprazole sodium sesquihydrate," Journal of Pharmaceutical and Biomedical Analysis, vol. 22, no. 1, pp. 45-58, 2000.

[30] M. I. Walash, M. E. S. Metwally, M. Eid, and R. N. El-Shaheny, "Spectrophotometric determination of risedronate in pharmaceutical formulations via complex formation with $\mathrm{Cu}(\mathrm{II})$ ions: application to content uniformity testing," International Journal of Biomedical Science, vol. 4, no. 4, pp. 303-309, 2008.

[31] J. J. Lingane, Electroanalytical Chemistry, Interscience, New York, NY, USA, 2nd edition, 1958.

[32] S. A. Tirmizi, F. H. Wattoo, M. H. S. Wattoo, S. Sarwar, A. N. Memon, and A. B. Ghangro, "Spectrophotometric study of stability constants of cimetidine-Ni(II) complex at different temperatures," Arabian Journal of Chemistry, vol. 35, no. 1, pp. 93-100, 2010.

[33] J. Inczedy, Analytical Application of Complex Equilibriia, Budapest, John Wiley \& Sons, 1976.

[34] J. H. Yoe and A. L. Jones, "Ccrforimetric determination of iron with disodium-1,2-dlhydroxybenzene-3,5-disuffonate," Industrial and Engineering Chemistry, vol. 16, pp. 111-115, 1944.

[35] International Conference on Harmonisation, ICH, of Technical Requirments for Registeration of Pharmaceuticals for Human Use, 2005. 

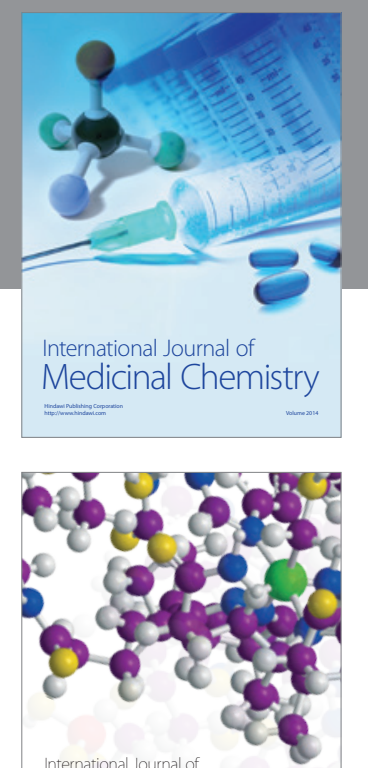

\section{Carbohydrate} Chemistry

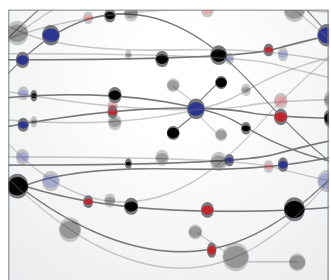

The Scientific World Journal
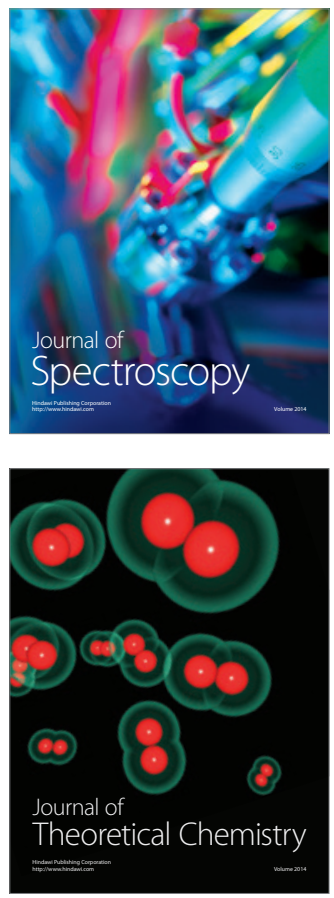
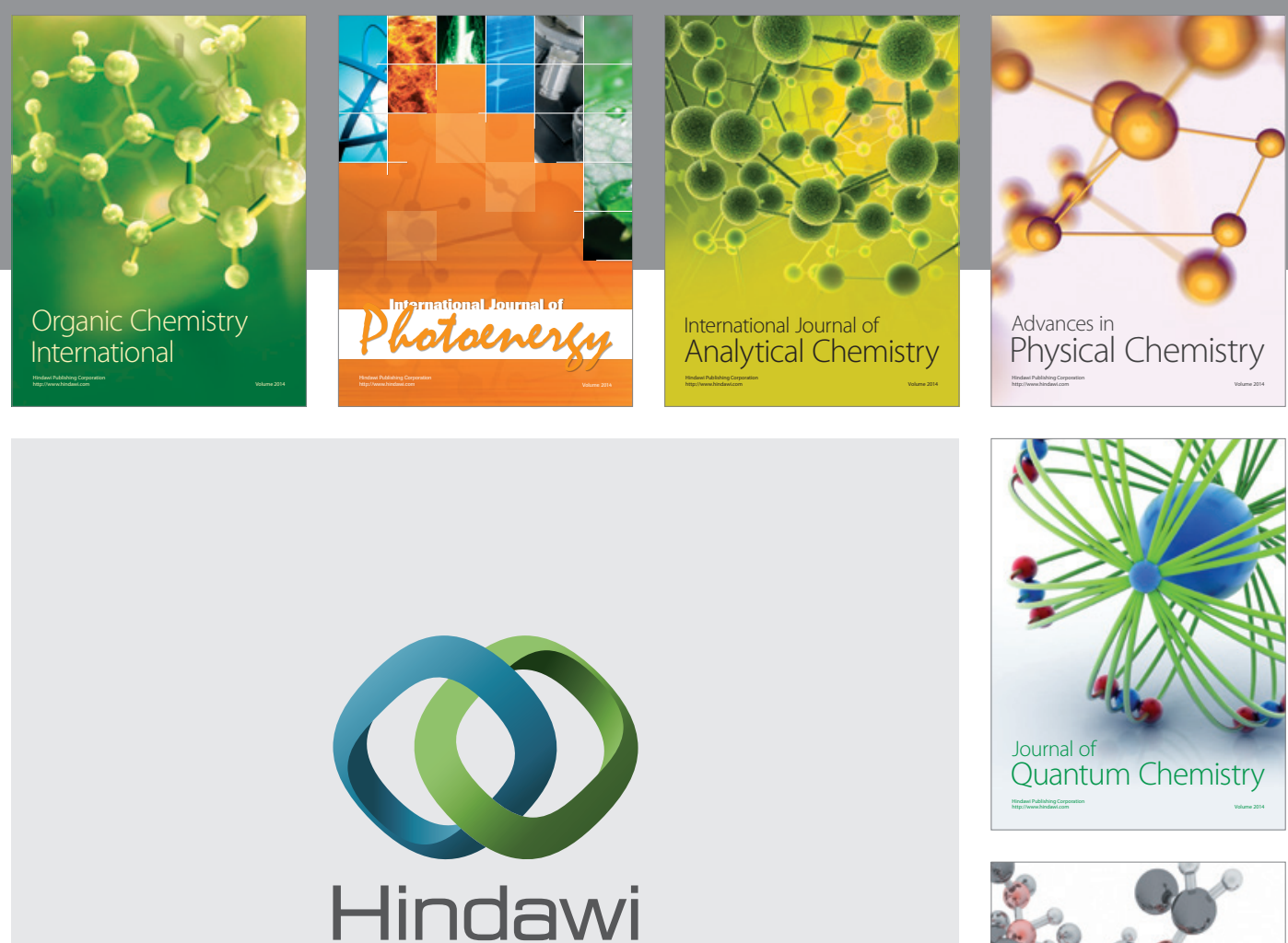

Submit your manuscripts at

http://www.hindawi.com

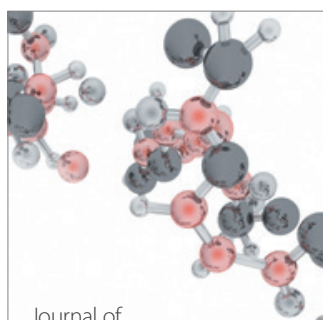

Analytical Methods

in Chemistry

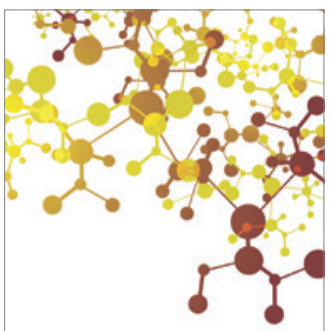

Journal of

Applied Chemistry

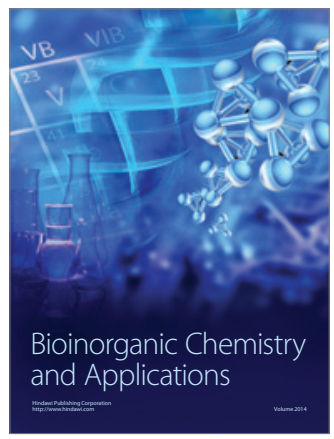

Inorganic Chemistry
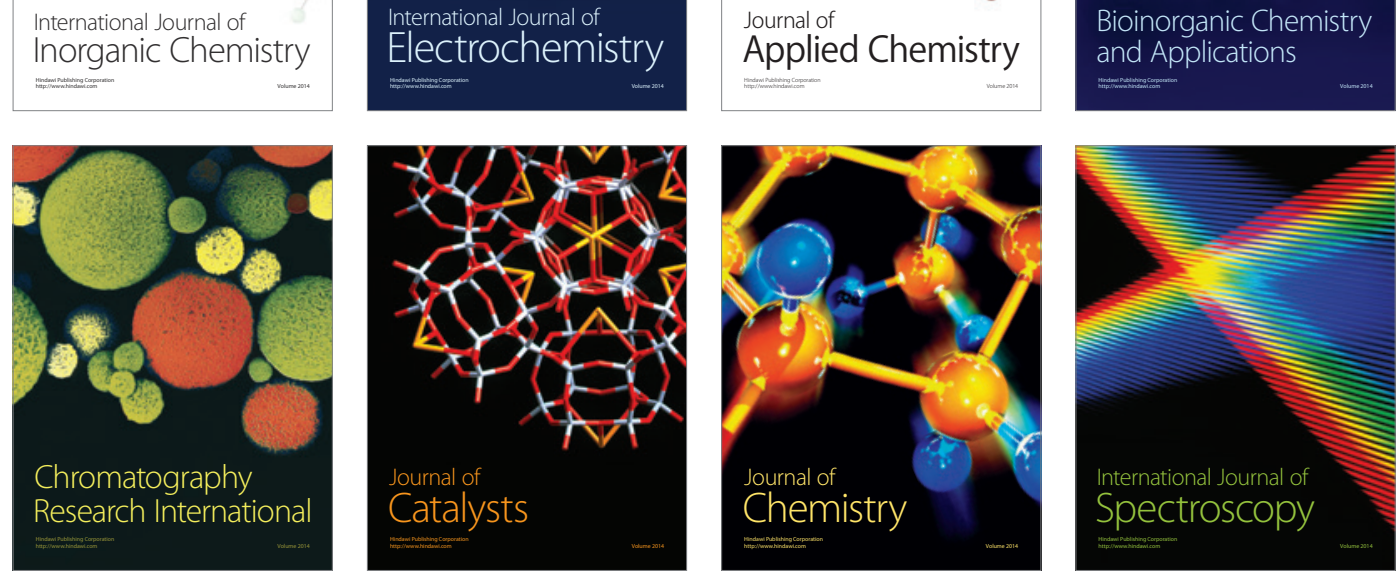